\title{
Analisa Ketelitian Geometrik Citra Pleiades 1A dan Worldview-2 untuk Pembuatan Peta Dasar Rencana Detail Tata Ruang Perkotaan (Studi Kasus: Surabaya Pusat)
}

\author{
Ricko Buana Surya, Bangun Muljo Sukojo, Husnul Hidayat \\ Jurusan Teknik Geomatika, Fakultas Teknik Sipil dan Perencanaan, Institut Teknologi Sepuluh Nopember (ITS) \\ Jl. Arief Rahman Hakim, Surabaya 60111 Indonesia \\ e-mail: bangunms@gmail.com
}

\begin{abstract}
Abstrak-Perkembangan teknologi penginderaan jauh mulai banyak diterapkan untuk berbagai keperluan, misalnya pembuatan peta Rencana Detail Tata Ruang (RDTR) dengan skala 1:5000. Saat ini, ada beberapa satelit yang dapat menghasilkan citra resolusi tinggi dengan resolusi spasial kurang dari 1-2 m. Namun data citra yang diperoleh dari satelit-satelit tersebut harus diolah sedemikian rupa untuk meminimalisasi adanya kesalahan, terutama kesalahan geometrik. Data citra Pleiades 1A tahun 2015 dan citra Worldview-2 tahun 2012. Kedua citra tersebut dikoreksi secara geometrik menggunakan dua metode transformasi yaitu affine dan polynomial orde-2. Proses koreksi geometrik dengan menggunakan 8 titik kontrol tanah (GCP) tersebar merata pada keseluruhan area studi yaitu Surabaya Pusat. Koordinat GCP diukur langsung di lapangan menggunakan GPS geodetik dengan metode statik dan lama pengamatan untuk setiap titik sekitar $\mathbf{4 0}$ menit. Kemudian citra terkoreksi dilakukan uji ketelitian koordinat dengan menggunakan ICP sebanyak 12 titik. Hasil penelitian ini menunjukkan bahwa nilai RMSE menggunakan metode transformasi polynomial orde-2 lebih baik dibandingkan dengan metode affine. Citra Worldview-2 menghasilkan nilai RMSE lebih kecil dibandingkan dengan citra Pleiades 1A pada kedua metode transformasi yang digunakan. Untuk kelayakan citra sebagai peta dasar, citra Pleiades 1A memenuhi syarat peta skala 1:5000 dan citra Worldview-2 memenuhi syarat peta skala 1:5000.
\end{abstract}

Kata Kunci-Koreksi Geometrik, Pleiades 1A, RMSE, Worldview -2

\section{PENDAHULUAN}

$\mathrm{K}$ OTA Surabaya merupakan salah satu kota metropolitan terbesar kedua setelah Jakarta. Luas wilayahnya kurang lebih $326,36 \mathrm{~km}^{2}$ yang terbagi dalam 31 kecamatan dan 163 desa/kelurahan dengan jumlah penduduk berjumlah 2.909.257 jiwa [3]. Posisi geografis yang berdekatan dengan pantai menjadikan Surabaya berpotensi sebagai tempat persinggahan dan permuiman bagi pendatang (imigran). Kota ini menjadi pusat bisnis, perdagangan, industri, dan pendidikan di Jawa Timur. Kemiringan lereng di Kota Surabaya dikategorikan menjadi dua, yaitu datar (0 $8 \%)$ dan landai $(8-15 \%)$. Secara umum Kota Surabaya didominasi kelas kemiringan lereng datar $(0-8 \%)$ sebesar $79 \%$ dan $21 \%$ dengan kelas kemiringan lereng landau $(8-15 \%)$ dari total luasan wilayah Surabaya [2].
Pengelolaan wilayah yang tepat sangat dibutuhkan untuk memaksimalkan potensi yang ada. Perlunya pemanfaatan ruang yang efektif dan efisien diwujudkan melalui proses penataan ruang. Dalam UU no. 26 tahun 2007 pasal 11 telah diamanatkan bahwa pemerintah daerah kota mempunyai wewenang dalam pelaksanaan penataan ruang wilayah kota yang meliputi perencanaan tata ruang wilayah kota, pemanfaatan ruang wilayah kota dan pengendalian pemanfaatan ruang wilayah kota. Pada setiap kota maupun kabupaten mempunyai Rencana Tata Ruang Wilayah (RTRW) masing-masing yang sesuai dengan aspek dan kondisi yang ada. RTRW kota atau kabupaten masih berupa recana umum yang kemudian dirinci lebih mendetail menjadi Rencana Detail Tata Ruang (RDTR) Kota dan Rencana Tata Ruang (RTR) Kawasan Strategis Kota. Kota Surabaya dibagi menjadi dua belas bagian unit pengembangan yang diatur dalam Perda no. 12 tahun 2014 pasal 19 yaitu unit pengembangan I Rungkut, II Kertajaya, III Tambak Wedi, IV Dharmahusada, V Tanjung Perak, VI Tunjungan, VII Wonokromo, VIII Dukuh Pakis, IX Ahmad Yani, X Wiyung, XI Tambak Oso Wilangun, XII Sambikerep.

Ketentuan mengenai peta pola ruang RDTR meliputi skala atau tingkat ketelitian minimal 1:5000 dan mengikuti ketentuan mengenai sistem informasi geografis yang dikeluarkan oleh kementerian/lembaga yang berwenang, mencakup ruang darat dan/atau ruang laut dengan batasan empat mil diukur dari garis pantai, dan dapat digambarkan dalam beberapa lembar peta yang tersusun berurutan mengikuti ketentuan yang berlaku [1]. Dengan peta skala 1:5000 atau lebih besar akan terlihat blok-blok dengan jelas, juga unsur lainnya seperti saluran, pagar, dsb.

Perkembangan teknologi penginderaan jauh telah banyak membantu untuk mendapatkan informasi yang ada di permukaan Bumi. Teknologi ini dapat memetakan area yang luas dalam waktu yang relatif singkat. Contohnya, citra Pleiades 1A dan Worldview2. Citra Pleiades 1A memiliki resolusi spasial 0,5 meter pada sensor pankromatik, 2 meter pada sensor multispektral [5] dan citra Worldview-2 memiliki resolusi spasial 0,46 meter pada sensor pankromatik, 1,84 meter pada sensor multispektral [4]. Dengan demikian kedua citra berpotensi sebagai sumber data untuk pembuatan peta skala besar. Namun perlu dilakukan analisis ketelitian geometrik terlebih dahulu. Oleh karena itu, penelitian ini bertujuan untuk menganalisis ketelitian geometrik citra Worldview2 dan Pleiades 1A untuk pembuatan peta dasar Rencana Detail Tata Ruang (RDTR) Perkotaa wilayah Surabaya Pusat. 


\section{METODOLOGI PENELITIAN}

\section{A. Lokasi Penelitian}

Lokasi penelitian ini dilakukan di Surabaya Pusat meliputi empat kecamatan yaitu Kecamatan Simokerto, Kecamatan Bubutan, Kecamatan Genteng dan Kecamatan Tegalsari seperti yang ditunjukkan pada Gambar 1.

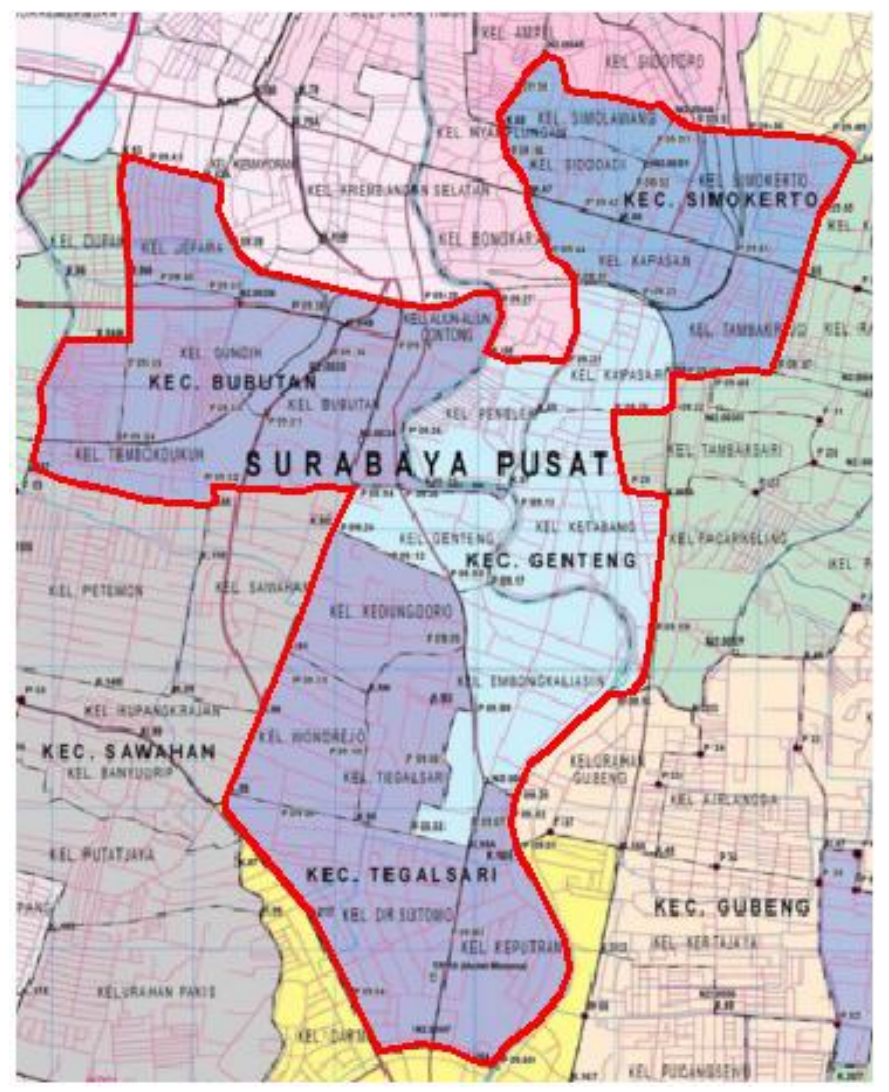

Gambar 1 Lokasi Penelitian

\section{B. Data dan Peralatan}

a. Data

Data yang digunakan dalam penelitian tugas akhir ini yaitu:

1. Citra Pleiades 1A wilayah Surabaya pada tahun 2015

2. Citra Worldview-2 wilayah Surabaya pada tahun 2012

3. Titik Kontrol Tanah (GCP) dan Data Independent Check Point (ICP)

4. Batas Administrasi

b. Peralatan

Peralatan yang digunakan dalam penelitian tugas akhir ini yaitu:

1. Perangkat Lunak (Sofware) yang digunakan dalam pengerjaan Peneliaan ini tugas akhir ini antara lain:

i. ArcGIS 10.2.2

ii. Topcon Tools

2. Peralatan lain yang digunakan untuk survei lapangan:

i. GPS Geodetik

ii. Roll Meter

\section{Tahap Pengolahan Data}

Adapun tahap pelaksanaan penelitian ini dapat dilihat pada diagram alir di bawah ini: a. Data

Data-data yang akan diolah meliputi data citra Pleiades 1A dan Worldview-2 pada wilayah Surabaya pada tahun 2015, data koordinat titik kontrol (GCP), koordinat ICP dan batas administrasi Surabaya.

b. Pembuatan desain jaring

Mendesain jaring dilakukan dengan meletakkan titik kontrol menyebar ke seluruh area studi. Kemudian nilai Strength of Figure (SoF) dihitung. Apabila hasil SoF kurang dari satu maka masuk ke tahap selanjutnya dan apabila lebih dari proses mendesain jaring diulangi lagi.

c. Pengukuran Titik Kontrol

Koordinat titik kontrol (GCP) diukur dengan GPS menggunakan metode jaring bebas dengan lama pengamatan \pm 40 menit. GCP yang diukur sebanyak 8 titik. Untuk data koordinat ICP sebanyak 12 titik diukur menggunakan metode radial dengan lama pengamatan \pm 10 menit.

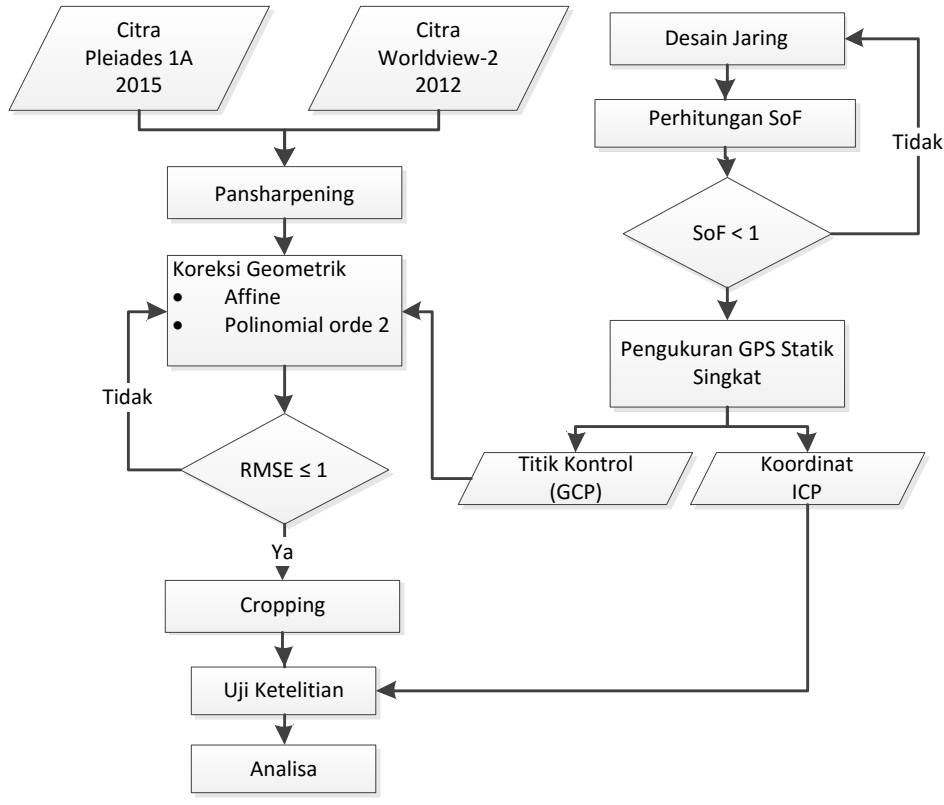

Gambar 2 Tahap Pengolahan Data

\section{d. Koreksi geometrik}

Koreksi geometrik pada kedua citra dilakukan menggunakan data koordinat titik kontrol (GCP) yang telah diukur di lapangan. Menggunakan metode affine dan polynomial orde-2. Apabila hasil nilai RMSE $\leq 1$ maka koreksi yang dilakukan sudah benar dan bisa melanjutkan ke tahap berikutnya, apabila sebaliknya maka proses ini diulangi kembali.

e. Pemotongan citra

Data citra Pleiades 1A dan Worldview-2 yang telah dikoreksi, dipotong sesuai dengan area studi. Proses ini bertujuan untuk meringankan proses yang dilakukan perangkat lunak pada tahap selanjutnya.

\section{f. Uji Ketelitian}

Uji ketelitian dilakukan untuk mengetahui perbedaan antara data pengukuran lapangan dengan data pada hasil rektifikasi citra. Uji ketelitian dilakukan menggunakan koordinat ICP yang tingkat ketelitiannya diketahui dari nilai RMSe koordinat.

g. Analisa 
Dari hasil perhitungan RMSE kedua citra dilakukan analisa nilai RMSE keseluruhan dari kedua metode transformasi dan nilai RMSE per titik pada kedua citra dan metode kedua transformasi. Kemudian nilai RMSE tersebut dikalikan dengan koefisien ketelitian untuk mengetahui tingkat kelayakan citra sebagai peta dasar untuk skala tertentu.

\section{HASIL DAN PEMBAHASAN}

\section{A. Penentuan Lokasi Titik Kontrol}

Lokasi titik kontrol tanah (Ground Control Point / GCP) sangat mempengaruhi Root Mean Square Error (RMSE) dari proses koreksi geometrik yang akan dilakukan. Oleh karena itu penentuan lokasi GCP diletakkan pada daerah yang mudah untuk diintrepetasi pada citra yang digunakan dan mudah diakses. Sebagai contoh, GCP diletakkan pada ujung jalan atau jembatan. Objek tersebut mudah dikenali pada citra dan kemungkinan perubahan pada objek tersebut relatif lama. Pada Gambar 3, T05 terletak pada taman segitiga di dekat stasiun Gubeng Lama.

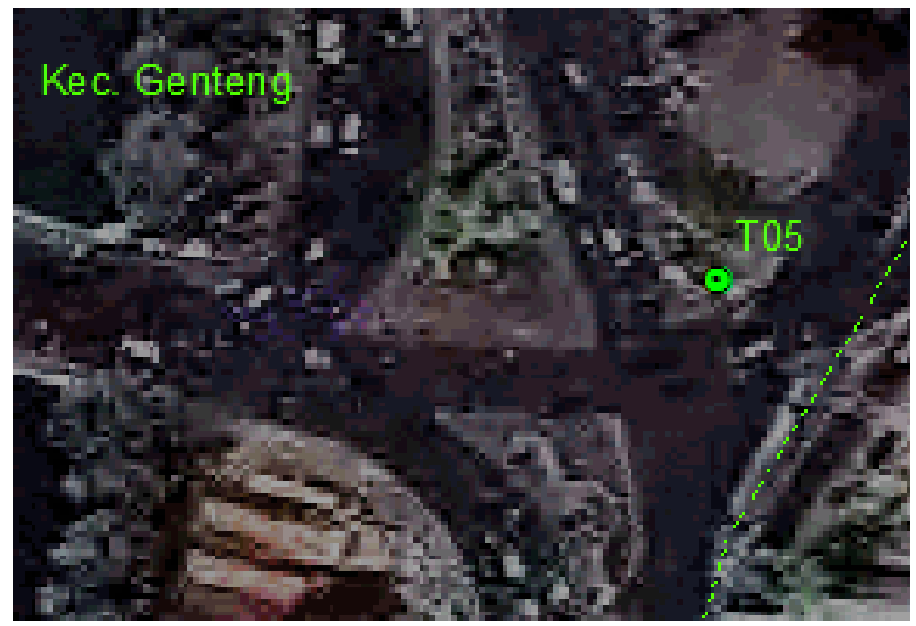

Gambar 3 Lokasi Titik Kontrol T05

\section{B. Kekuatan Desain Jaring}

Desain jaring dibuat sebelum melakukan pengukuran GCP di lapangan menggunakan GPS agar hasil pengukuran GCP lebih teliti. Semakin kecil nilai faktor kekuatan jaring, maka akan semakin baik konfigurasi jaring yang bersangkutan, dan sebaliknya.

Perhitungan nilai faktor kekuatan jaring ini menggunakan metode kuadrat terkecil (least square) dengan komponenkomponen sebagai berikut:

- Jumlah titik (S) = 8

- Jumlah baseline $(\mathrm{N})=14$

- $\mathrm{SoF}=0,165$

\section{Koordinat Titik Kontrol}

Koordinat titik kontrol $(\mathrm{X}, \mathrm{Y})$ didapatkan dari pengukuran GPS geodetik di lapangan. Koordinat ini digunakan untuk acuan koreksi geometrik citra Pleiades 1A dan Worldview-2. Berikut ini merupakan daftar koordinat titik kontrol yang digunakan:
Tabel 1.

Daftar Koordinat GCP

\begin{tabular}{cccc}
\hline \hline \multirow{2}{*}{ No. } & Nama & \multicolumn{2}{c}{ Titik Kontrol } \\
\cline { 3 - 4 } & Titik & $\mathbf{X}(\mathbf{m})$ & Y (m) \\
\hline 1. & T01 & 691846,058 & 9198302,417 \\
2. & T02 & 690153,933 & 9199234,103 \\
3. & T03 & 689965,145 & 9197721,513 \\
4. & T04 & 691264,435 & 9195455,960 \\
5. & T05 & 693364,163 & 9196444,317 \\
6. & T06 & 692629,784 & 9193947,153 \\
7. & T07 & 693111,339 & 9199847,221 \\
8. & T08 & 694070,306 & 9198407,818 \\
\hline \hline
\end{tabular}

\section{Perhitungan Root Mean Square Error (RMSE)}

Dari hasil tranformasi koordinat citra ke dalam koordinat titik kontrol yang dijadikan acuan akan didapatkan residu untuk masing-masing titik kontrol. Residu merupakan selisih antara koordinat yang dianggap benar (dalam hal ini yaitu koordinat dari pengukuran GPS) dengan koordinat hasil transformasi dari citra Pleiades 1A dan citra Worldview-2. Dari hasil tersebut dapat dihitung besar nilai RMSE sebagai berikut:

Tabel 2.

Perhitungan RMSE GCP Citra Pleiades 1A

\begin{tabular}{cccc}
\hline \hline \multirow{2}{*}{ No. } & \multirow{2}{*}{ Nama } & \multicolumn{2}{c}{ RMSE } \\
\cline { 3 - 4 } & Titik & Affine & Polynomial-2 \\
\hline 1. & T01 & 0,476 & 0,096 \\
2. & T02 & 0,561 & 0,177 \\
3. & T03 & 0,324 & 0,227 \\
4. & T04 & 0,445 & 0,058 \\
5. & T05 & 0,125 & 0,146 \\
6. & T06 & 0,479 & 0,162 \\
7. & T07 & 0,220 & 0,143 \\
8. & T08 & 0,233 & 0,172 \\
\multicolumn{2}{r}{ Total RMSE } & 0,386 & 0,155 \\
\hline \hline
\end{tabular}

Tabel 3.

Perhitungan RMSE GCP Citra Worldview-2

\begin{tabular}{cccc}
\hline \hline \multirow{2}{*}{ No. } & Nama & \multicolumn{2}{c}{ RMSE } \\
\cline { 3 - 4 } & Titik & Affine & Polynomial-2 \\
\hline 1. & T01 & 0,363 & 0,206 \\
2. & T02 & 0,311 & 0,067 \\
3. & T03 & 0,267 & 0,065 \\
4. & T04 & 0,194 & 0,106 \\
5. & T05 & 0,310 & 0,095 \\
6. & T06 & 0,068 & 0,200 \\
7. & T07 & 0,326 & 0,136 \\
8. & T08 & 0,351 & 0,121 \\
\multicolumn{2}{r}{ Total RMSE } & 0,289 & 0,134 \\
\hline \hline
\end{tabular}

Berdasarkan hasil pada Tabel 2 dan Tabel 3, citra Worldview2 memiliki nilai RMSE lebih kecil dibandingkan dengan citra Pleiades. Hal ini sesuai oleh perbedaan resolusi spasial pada kedua citra, dimana Worldview-2 memiliki nilai resolusi spasial yang lebih baik sehingga lebih mudah untuk melakukan identifikasi letak titik kontrol pada citra.

Untuk mengetahui perbedaan besar nilai RMSE setiap metode pada kedua citra dapat dilihat pada Gambar 4. 


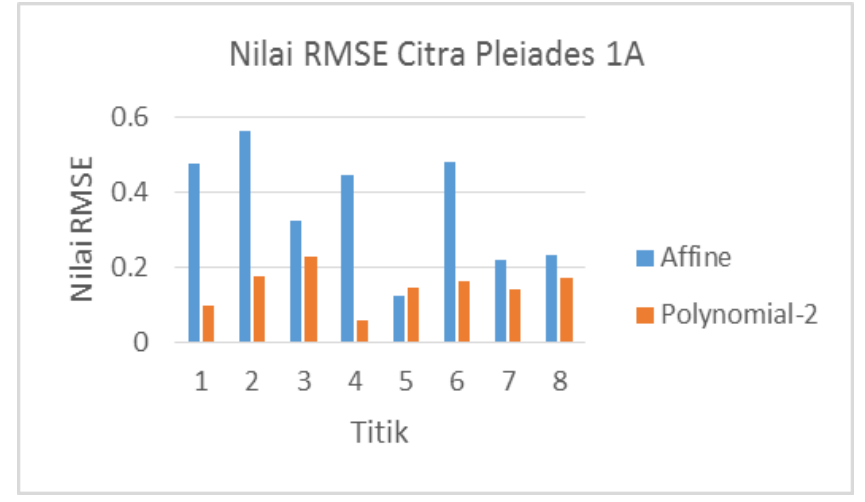

Gambar 4 Histogram Nilai RMSE Pleiades 1A

Berdasarkan hasil histogram pada Gambar 4 dan Gambar 5. Didapatkan hasil nilai RMSE menggunakan metode Polynomial Orde-2 memiliki nilai lebih kecil dibandingkan dengan menggunakan metode Affine. Hal ini dikarenakan metode Polynomial Orde-2 dengan 12 parameter merupakan pengembangan dari metode Affine dengan 6 parameter [6].

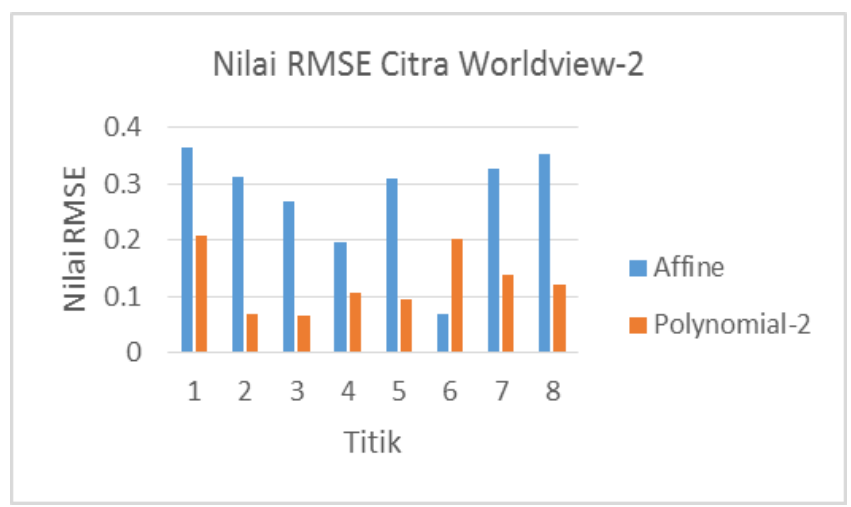

Gambar 5 Histogram Nilai RMSE Worldview-2

\section{E. Uji Ketelitian Horisontal}

Analisa ketelitian diperoleh dengan mencari residu dari data pengukuran ICP dan titik koordinat dari citra satelit setelah proses rektifikasi. Hasil residu tersebut digunakan untuk menghitung nilai RMSE koordinat citra. Koordinat hasil pengukuran ICP ditunjukakan pada Tabel 4.

Tabel 4.

Daftar Koordinat ICP

\begin{tabular}{ccc} 
& \multicolumn{2}{c}{ Daftar Koordinat ICP } \\
\cline { 2 - 3 } Titik & $\mathbf{X}(\mathbf{m})$ & $\mathbf{Y}(\mathbf{m})$ \\
\hline T 1 & 694108,879 & 9198612,655 \\
T 2 & 693640,407 & 9199102,751 \\
T 3 & 692877,559 & 9199909,09 \\
T 4 & 693283,812 & 9197556,329 \\
T 5 & 692449,896 & 9195600,341 \\
T 6 & 692778,524 & 9194507,983 \\
T 7 & 691800,692 & 9193915,303 \\
T 8 & 691611,653 & 9195294,417 \\
T 9 & 691544,76 & 9195898,458 \\
T 10 & 691202,939 & 9197823,059 \\
T 1 & 690463,726 & 9199083,534 \\
T 12 & 689930,056 & 9197895,756 \\
\hline \hline
\end{tabular}

Dari data residu koordinat lapangan dengan koordinat citra hasil rektifikasi diperoleh nilai RMSE koordinat citra yang ditunjukkan pada Tabel 5 untuk citra Pleiades 1A dan pada Tabel 6 untuk citra Worldview-2.

Tabel 5.

Hasil RMSe ICP Citra Pleiades 1A

\begin{tabular}{ccc}
\hline \hline \multirow{2}{*}{ Titik } & \multicolumn{2}{c}{ RMSE Titik } \\
\cline { 2 - 3 } & affine & polynomial-2 \\
\hline T 1 & 0,060 & 0,549 \\
T 2 & 0,523 & 0,469 \\
T 3 & 0,149 & 0,603 \\
T 4 & 0,466 & 0,557 \\
T 5 & 0,202 & 0,245 \\
T 6 & 0,233 & 0,406 \\
T 7 & 0,072 & 0,385 \\
T 8 & 0,186 & 0,703 \\
T 9 & 0,189 & 0,567 \\
T 10 & 0,620 & 0,435 \\
T 1 & 0,819 & 0,588 \\
T 12 & 0,491 & 0,397 \\
RMSE & 0,624 & 0,532 \\
\hline \hline
\end{tabular}

Tabel 6.

Hasil RMSe ICP Citra Worldview-2

\begin{tabular}{ccc}
\hline \multirow{2}{*}{ Titik } & \multicolumn{2}{c}{ RMSE Titik } \\
\cline { 2 - 3 } & affine & polynomial-2 \\
\hline T 1 & 0,451 & 0,451 \\
T 2 & 0,325 & 0,325 \\
T 3 & 0,419 & 0,392 \\
T 4 & 0,241 & 0,241 \\
T 5 & 0,751 & 0,351 \\
T 6 & 0,235 & 0,335 \\
T 7 & 0,271 & 0,271 \\
T 8 & 0,498 & 0,498 \\
T 9 & 0,208 & 0,208 \\
T 10 & 0,777 & 0,329 \\
T 11 & 0,311 & 0,311 \\
T 12 & 0,223 & 0,223 \\
RMSE & 0,436 & 0,406 \\
\hline \hline
\end{tabular}

Dari tabel diatas terlihat RMSE ICP citra Pleiades 1A dan Worldview-2 dari hasil rektifikasi menggunakan metode affine masing-masing sebesar 0,624 $\mathrm{m}$ dan 0,463 $\mathrm{m}$. Nilai RMSE ICP citra Pleiades 1A dan Worldview-2 dari hasil rektifikasi menggunakan metode polynomial orde-2 masing-masing sebesar $0,532 \mathrm{~m}$ dan $0,406 \mathrm{~m}$. Sehingga citra Worldview-2 memiliki ketelitian lebih tinggi dibandingkan dengan citra Pleiades 1A, sedangkan metode yang lebih baik adalah polynomial orde-2.

\section{F. Analisa Kelayakan Citra}

Menurut Perka BIG Nomor 15 Tahun 2014, ketentuan ketelitian geometri horizontal setiap peta adalah sebagai berikut:

Tabel 7.

Ketelitian Geometri Peta

\begin{tabular}{ccc}
\hline \hline \multirow{2}{*}{ No. } & \multirow{2}{*}{ Skala Peta } & Ketelitian $(\mathbf{m})$ \\
\cline { 3 - 3 } & & $\mathbf{1 , 5 1 7 5} \mathbf{x}$ RMSE \\
\hline 1. & $1: 5000$ & 1 \\
2. & $1: 2500$ & 0,5 \\
3. & $1: 1000$ & 0,2 \\
\hline \hline
\end{tabular}

Berdasarkan perhitungan perkalian nilai RMSE berdasarkan hasil metode polynomial orde-2 dengan koefisien ketelitian diperoleh ketelitian pada citra Pleiades 1A sebesar 0,807 m dan 
citra Worldview-2 sebesar 0,616 m. Sehingga citra Pleiades 1A memenuhi syarat peta skala 1:5000 dan citra Worldview-2 memenuhi syarat peta skala 1:5000.

\section{KESIMPULAN DAN SARAN}

Kesimpulan dari penelitian ini adalah sebagai berikut.

a. Dari hasil perhitungan transformasi koordinat didapatkan nilai RMSE menggunakan metode affine sebesar 0,386 pada citra Pleiades 1A dan 0,289 pada citra Worldview-2. Sedangkan, nilai RMSE menggunakan metode polynomial orde-2 sebesar 0,155 pada citra Pleiades 1A dan 0,134 pada citra Worldview-2.

b. Dari perhitungan RMSE GCP, pada metode affine nilai RMSE per titik terkecil sebesar 0,125 pada citra Pleiades 1 A dan 0,068 pada citra Worldview-2. Sedangkan nilai RMSE per titik terbesar sebesar 0,561 pada citra Pleiades 1A dan 0,363 pada citra Worldview-2. Pada metode polynomial orde-2 nilai RMSE per titik terkecil sebesar 0,058 pada citra Pleiades 1A dan 0,065 pada citra Worldview-2. Sedangkan nilai RMSE per titik terbesar sebesar 0,227 pada citra Pleiades 1A dan 0,206 pada citra Worldview-2.

c. Dari hasil uji ketelitian koordinat menggunakan ICP didapatkan nilai RMSE dari hasil rektifikasi metode affine pada citra Pleiades 1A sebesar 0,624 m dan pada citra Worldview sebesar 0,436 m. Untuk nilai RMSE dari hasil rektifikasi metode polynomial orde-2 pada citra Pleiades 1A sebesar 0,532 $\mathrm{m}$ dan pada citra Worldview sebesar $0,406 \mathrm{~m}$.

d. Untuk kelayakan citra sebagai peta dasar, citra Pleiades 1A memenuhi syarat peta skala 1:5000 dan citra Worldview-2 memenuhi syarat peta skala 1:5000.

Saran yang dapat diberikan untuk penelitian selanjutnya adalah sebagai berikut. Jumlah titik kontrol menyesuaikan dengan luasan area studi, misalkan untuk luas area $<250 \mathrm{~km}^{2}$ maka jumlah titik kontrol minimal sebanyak 10 titik dengan persebaran titik diletakkan pada objek yang mudah dikenali sepeti pojok bangunan.

\section{PENUTUP}

Penulis menyadari bahwa jurnal ini masih banyak kekurangan baik dalam penulisan maupun isi dari jurnal ini, karena itu kami sangat mengharapkan saran dan kritik yang membangun guna perbaikan kelak. Akhir kata, penulis menyampaikan banyak terima kasih.

\section{DAFTAR PUSTAKA}

[1] Baihaqi, Isfandiar, 2013. Aspek Perpetaan untuk Penyusunan Rencana Detail Tata Ruang (RTDR). Jakarta: Badan Informasi Geospasial.

[2] BLH, 2011. Profil Keanekaragaman Hayati. Surabaya: Badan Lingkungan Hidup.

[3] BPS, 2015. Surabaya dalam Angka 2015. Surabaya: Badan Pusat Statistik.

[4] LAPAN, 2015. Spesifikasi Citra Satelit Worldview-2. http://pusfatekgan.lapan.go.id/wp-content/uploads/2015/02/InformasiSatelit-WV2.pdf. (diakses Januari 24, 2016).
[5] LAPAN, 2015. Spesifikasi Citra Satelit Pleiades. http://pusfatekgan.lapan.go.id/wp-content/uploads/2015/02/InformasiSatelit-PL.pdf. (diakses Januari 24, 2016).

[6] Mohammed, N.Z. \& Eiman Eisa. "The Effect of Polynomial Order on Georeferencing Remote Sensing Images." International Journal of Engineering and Innovative Technology (IJEIT), 2013: Volume 2, Issue 8. 